\title{
Foreign Direct Investment and Productivity Spillovers: the Experience of ASEAN Countries
}

\author{
Nathapornpan PIYAAREEKUL UTTAMA
}

Mae Fah Luang University

Nicolas PERIDY

Université du Sud Toulon-Var

\begin{abstract}
This paper aims at investigating the productivity spillover effects of FDI inflows to ASEAN countries. A first contribution is related to the development of an original theoretical model of complex multinational firms which simultaneously explores backward and forward linkages due to FDI. As a second contribution, the significance of vertical productivity spillovers in ASEAN countries is tested empirically. For that purpose, and given the lack of data at firm level, the causal relationship between FDI and productivity is investigated by using countryspecific data. Several alternative causality tests are implemented, including both direct and indirect approaches. The main results give strong evidence that FDI causes productivity growth in ASEAN countries. These results correlate the prediction of the theoretical model, which provide a strong support for the relationship between FDI and productivity spillovers.
\end{abstract}

- JEL Classification: F21

- Key Words: ASEAN, FDI, Spillover Effects, Panel Data

\footnotetext{
*Corresponding address: Nathapornpan PIYAAREEKUL UTTAMA; Mae Fah Luang University, Economics Program, School of Management, 333 Moo 1 Tasud, Muang, Chiang Rai, Thailand, Tel: +66 53916698 , Fax: +66 5391 6694, e-mail: n_piyaareekul@hotmail.com/ Nicolas PERIDY; Universite du Sud Toulon-Var (LEAD, France), UFR Sciences Economiques et Gestion Avenue de l'Université, BP 20132, F-83957 LA GARDE Cedex, France, Tel: +33 618039 201, Fax: +33 494142 165, e-mail: nicolas.peridy@univ-tln.fr. (C2010-Center for International Economics, Sejong Institution, Sejong University, All Rights Reserved.
} 


\section{Introduction}

In the past decade and until the financial and economic crisis of the late 2000s, FDI flows concerning ASEAN countries have exhibited huge growth rates, especially more than $+50 \%$ from 2005 to 2007 . Consequently, as a percentage of world FDI, ASEAN inflows jumped from $1.6 \%$ in 2000 to $4.4 \%$ in 2007 . IntraASEAN FDI has also grown spectacularly, from 3.8 billion dollars in 2005 to 8.1 billion in 2007 (ASEAN Secretariat, 2008c). In this regard, the various government policies in favor of FDI liberalization are likely to have contributed to this outcome.

One crucial question concerns the potential impact of such FDI growth rates on domestic ASEAN economies. In this regard, the existing theoretical and empirical literature gives part of the answer. Starting with the theoretical one, it identifies several direct effects, such as production, employment and trade effects (Navaretti and Venables, 2004). Similarly, indirect effects reflect the impact of FDI on the demand for inputs of both Multinational Enterprises (MNEs) and local firms. This creates backward linkages to local suppliers which raises productivity. These productivity effects include both horizontal and vertical spillovers.

Vertical productivity spillovers are particularly interesting, since they take into account the relationships across industries (inter-industry spillovers), through backward and forward linkages to input markets. Surprisingly, there is still little theoretical work on vertical spillovers. The two main existing references are Markuzen and Venables (1999) as well as Lin and Saggi (2005). Although these two models provide a strong theoretical support for the idea that FDI can play a crucial role in productivity spillovers through backward linkages to the host economy, they do not explore the forward linkages between upstream and downstream industries.

The empirical literature on productivity spillovers generally provides mixed results. This lack of strong evidence for significant spillover effects can be explained by the quality of the data and the choice of the empirical technique (Görg and Greenaway, 2004). Another characteristic of the empirical literature is the limitation of the number of studies concerning developing countries, including ASEAN countries. This is mainly due to the lack of data at firm-level.

This paper proposes additional investigation of vertical productivity spillover applied to ASEAN countries. Its main contributions are the following. First, we provide an original theoretical model which simultaneously explores backward and 
forward linkages. To that end, we start modeling complex multinational activities in a Knowledge-Capital model, following Baltagi and al. (2007). From this model, we explore the demand effect side of FDI like Markusen and Venables (1999), but extended to horizontal and vertical multinational activities (complex FDI) and related to both the upstream and the downstream industries. This model makes it possible to derive a proposition, which shows that the entry of multinationals gives rise to spillover effects through backward linkages that expand the intermediate production in the upstream industry. This in turn gives rise to a decrease in price and a productivity increase in the downstream industry, through forward linkages.

As a second contribution, we test empirically the significance of vertical productivity spillovers in ASEAN countries. Given the lack of data at firm level for these countries, we focus on the causal relationship between FDI and productivity by using country-specific data. In this regard and as a sensitivity analysis, several alternative causality tests are implemented, including both direct and indirect approaches. The main results give strong evidence that FDI causes productivity growth in ASEAN countries. These results correlate the prediction of the theoretical model, which provide a strong support for the relationship between FDI and productivity spillovers.

The remainder of this article is organized as follows: The section II describes recent patterns in FDI in ASEAN countries. It shows that the regional integration process has been accelerating in recent years, especially with regards to FDI liberalization. It also stresses that FDI has recorded a spectacular increase in recent years. Section III develops the theoretical model, which explores the relationship between FDI and productivity, through backward and forward linkages. Section IV tests empirically the causality between FDI and total factor productivity, while the last section discusses the policy implications of the results.

\section{Recent Patterns in Foreign Direct Investment in ASEAN Countries}

Since the late 90s, ASEAN countries have implemented far reaching policies for trade and FDI liberalization, both at regional and multilateral levels In fact, the ASEAN investment area (AIA), launched in 1998, must be viewed as complementary with the trade integration process (Asean Free Trade Area). Indeed, it aims to facilitate free flows of direct investment, technology and skilled labour (ASEAN Secretariat, 1998). The main provisions of this agreement first covered 
specific industries, such as manufacturing, agriculture, mining and quarrying, forestry, fisheries as well as services. In the 2003 agreement, all industries have been included with regard first to all ASEAN investors by 2010 before the extension to world investors by 2020 (ASEAN Secretariat, 2003). National treatment has also been provided for ASEAN investors.

Although some studies consider that progress toward free FDI was slower than for trade (Habito et al. 2004), the AIA process has recently been deepened, through enhanced external linkages, joint consultation with the private sector, various capacity-building programs as well as investment promotion activities with regard to the priority sectors mentioned previously (ASEAN Secretariat, 2007a and 2007b). Moreover, the ASEAN Comprehensive Investment Agreement (ACIA) was carried out in 2007. The key features of the ACIA agreement include an enhancement on the existing AIA agreement with regard to investment liberalization, facilitation, protection and promotion. In particular, this new agreement grants immediate benefits to both ASEAN investors and ASEAN-based foreign investors by 2015 . In this regard, it shortens the deadline to achieve a free and open investment environment, initially expected by 2020. It also provides clearer definitions in line with international investment agreements. Finally, it also covers portfolio investments, with reservations taken if necessary and as appropriate (ASEAN Secretariat, 2008b).

Figure 1 and Table 1 give an overview of recent patterns in FDI in the ASEAN

Figure 1. FDI Inflows to ASEAN Countries (2000-2007)

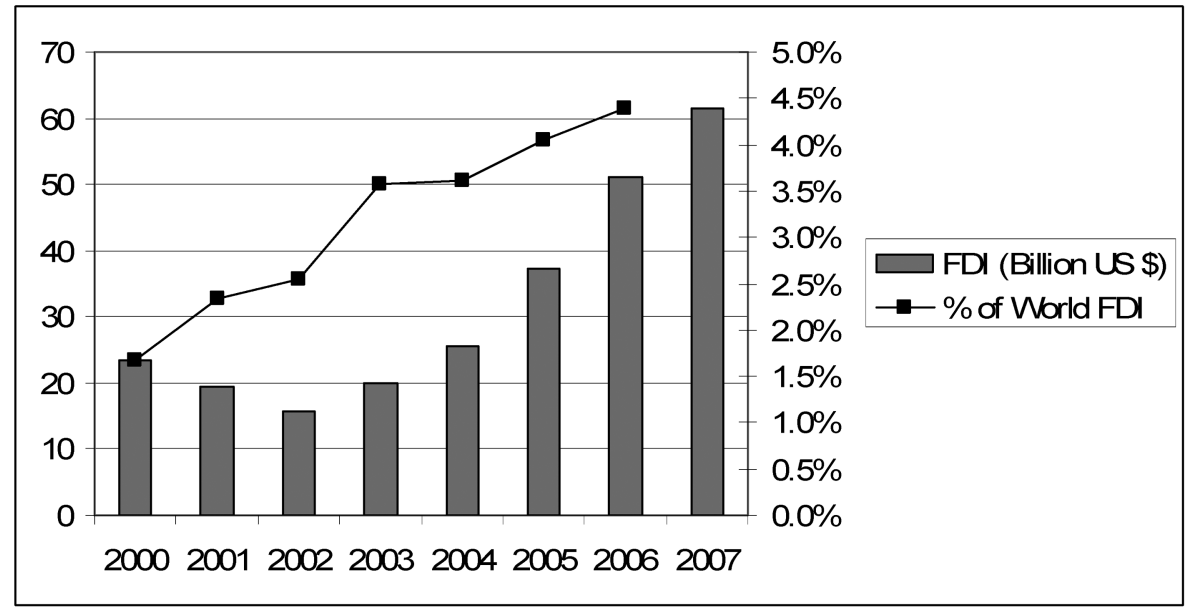

Source: ASEAN FDI Statistics and ASEAN Secretariat (2007b) 
Table 1. FDI Flows to ASEAN Countries: 1995-2006 (million US\$)

\begin{tabular}{|c|c|c|c|c|c|c|c|c|c|c|c|c|}
\hline & 1995 & 1996 & 1997 & 1998 & 1999 & 2000 & 2001 & 2002 & 2003 & 2004 & 2005 & 2006 \\
\hline$\overline{\text { Brunei }}$ & & & & & & & & & & & & \\
\hline $\begin{array}{l}\text { Darus- } \\
\text { salam }\end{array}$ & 584 & 654 & 702 & 573 & 748 & 549 & 526 & 1,035 & 3,123 & 212 & 289 & 434 \\
\hline Cambodia & 151 & 294 & 168 & 243 & 232 & 149 & 149 & 145 & 84 & 131 & 381 & 438 \\
\hline Indonesia & 4,346 & 6,194 & 4,678 & -356 & $-2,745$ & $-4,550$ & $-3,279$ & 145 & -596 & 1,895 & 8,336 & 5,556 \\
\hline Lao & 88 & 128 & 86 & 45 & 52 & 34 & 24 & 25 & 20 & 17 & 28 & 187 \\
\hline Malaysia & 5,815 & 7,297 & 6,323 & 2,714 & 3,895 & 3,788 & 554 & 3,203 & 2,473 & 4,624 & 3,965 & 6,060 \\
\hline Myanmar & 318 & 581 & 879 & 683 & 304 & 208 & 192 & 191 & 291 & 251 & 236 & 143 \\
\hline $\begin{array}{l}\text { Philip- } \\
\text { pines }\end{array}$ & 1,577 & 1,618 & 1,261 & 1,718 & 1,247 & 2,240 & 195 & 1,542 & 491 & 688 & 1,854 & 2,345 \\
\hline Singapore & 11,503 & 9,303 & 13,533 & 7,594 & 16,067 & 16,485 & 15,649 & 7,200 & 11,664 & 19,828 & 15,002 & 24,055 \\
\hline Thailand & 2,070 & 2,338 & 3,882 & 7,491 & 6,091 & 3,350 & 5,061 & 3,335 & 5,235 & 5,862 & 8,957 & 10,756 \\
\hline Viet Nam & 1,780 & 1,803 & 2,587 & 1,700 & 1,484 & 1,289 & 1,300 & 1,200 & 1,450 & 1,610 & 2,021 & 2,360 \\
\hline $\begin{array}{l}\text { ASEAN } \\
\text { TOTAL }\end{array}$ & 28,231 & 30,209 & 34,099 & 22,406 & 27,375 & 23,541 & 20,372 & 18,023 & 24,235 & 35,117 & 41,068 & 52,380 \\
\hline
\end{tabular}

Source: ASEAN FDI Statistics and ASEAN Secretariat (2008c)

area. It is striking to observe that after a decline following the Asian crisis, there has been a very strong recovery in recent years. For example, FDI inflows in ASEAN increased by $20.5 \%$ in 2007 , after a $37.3 \%$ increase one year before. This is much more than world FDI increases. Consequently, as a percentage of world FDI, ASEAN inflows jumped from $1.6 \%$ in 2000 to $4.4 \%$ in 2007 . In this regard, the various government policies in favor of FDI liberalization are likely to have

Figure 2. Geographical Breakdown of FDI Inflows to ASEAN Countries

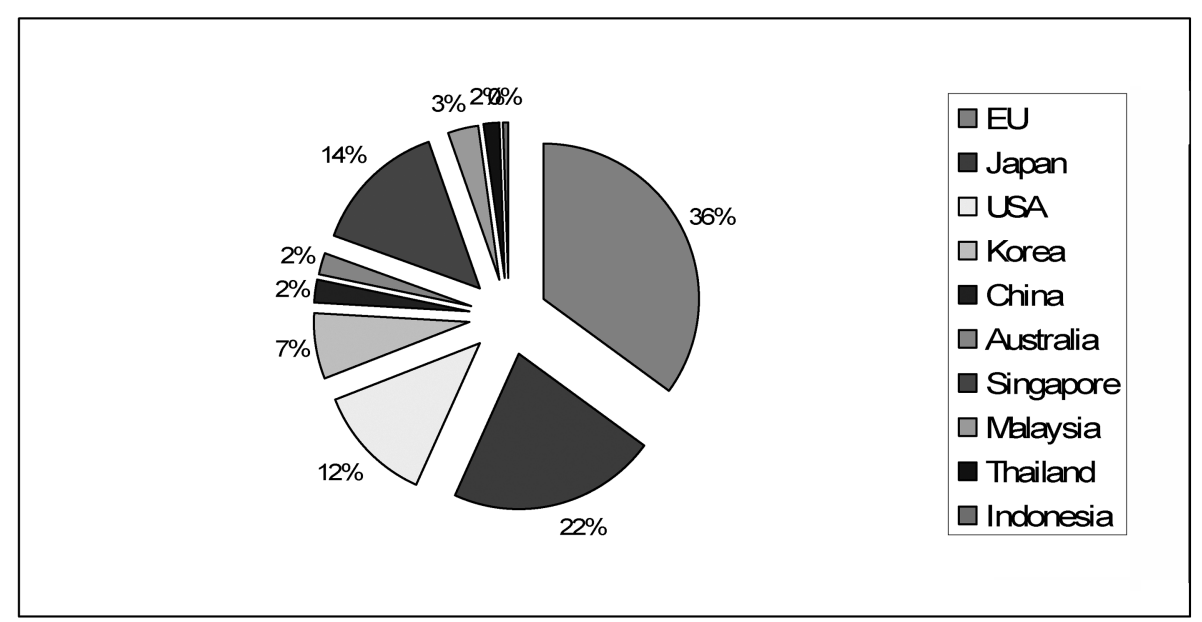

Source: ASEAN Secretariat (2008a) 
contributed to this outcome.

A geographical analysis shows that although the EU, ${ }^{1}$ the US and JAPAN still account for almost $70 \%$ of total FDI inflows in ASEAN, it is worth mentioning that intra-ASEAN FDI has increased tremendously in recent years, from 3.8 billion dollars in 2005 to 8.1 billion in 2007. As a result, intra-ASEAN flows nearly account for about 15\% of total FDI in 2007 (Figure 2). The other countries which exhibit the highest FDI growth rate in ASEAN countries are China and the Republic of Korea.

At sectoral level, manufacturing still accounts for the biggest share in ASEAN inflows, with almost one-third of total FDI. In 2006, the main manufacturing industries with substantial FDI interest were radio, television, communication equipment and apparatus; chemicals and chemical products; basic metals; machinery and equipment; non-metallic mineral products. Overall, FDI in the manufacturing industries doubled from 2002 to 2006, from 8.4 to 16.2 billion dollars.

With one-fourth of total FDI, financial intermediation and services are the second driving sector for FDI. However, after a substantial FDI rise in 2006 (from 4.3 to 12.3 billion dollars), this sector experienced a $43 \%$ decline in investment in 2007 as a result of global financial difficulties that arose in the early part of the

Figure 3. Sectoral Breakdown of FDI Inflows to ASEAN Countries

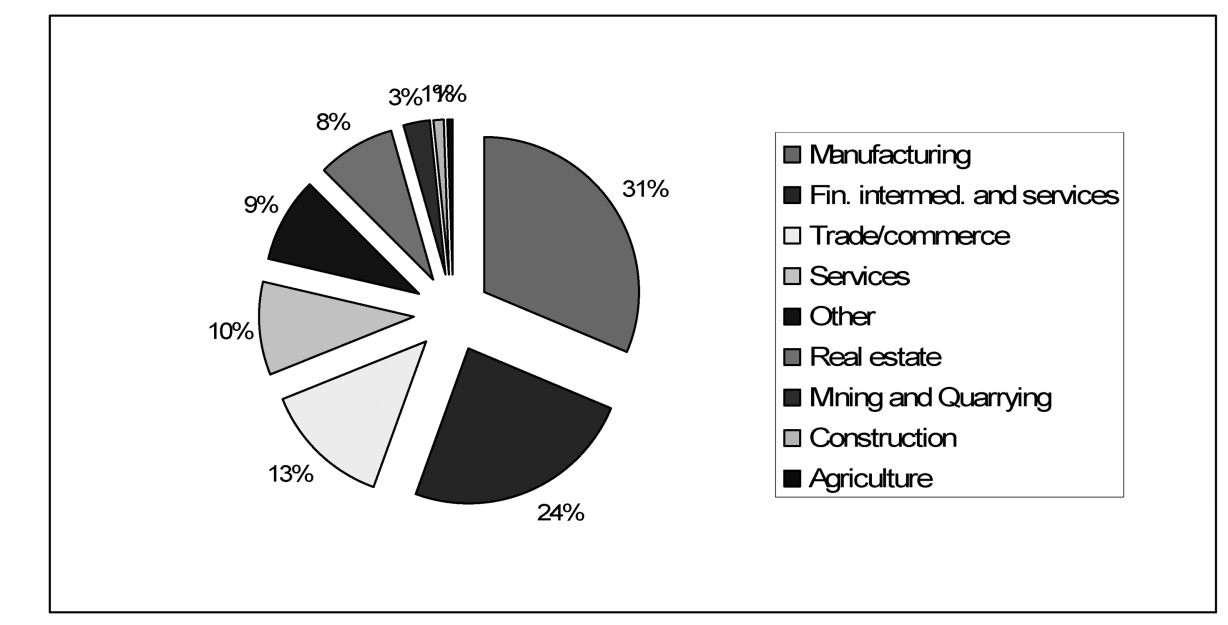

Source : ASEAN Secretariat (2008c)

${ }^{1}$ Mainly the UK and Germany. 
second half of 2007 (ASEAN Secretariat, 2008c). Nevertheless, this sector still remained in the top-three recipients of FDI in 2007. The last main industries in terms of FDI concern commerce and services ( $23 \%$ of total FDI) with a substantial and continuous rise in recent years. Conversely, the share of the traditional sectors (agriculture, mining and construction) is steadily decreasing.

Overall, ASEAN countries welcomed this good FDI performance in recent years, despite the slowdown observed in the late 2000s. To go further, the Council agreed to complete the ACIA by the 11th AIA Council Meeting in Singapore in August 2008. The following sections of this article aim to examine the relationship between these recent patterns in FDI and their consequences on productivity in the case of ASEAN countries.

\section{Productivity Spillovers of FDI: a Theoretical Approach}

As observed in the previous section, FDI policies in ASEAN countries have led to a substantial reduction in investment restriction, not only within the ASEAN area, but also with a large number of other countries. This integration process is likely to stimulate FDI within this region. Such an increase is expected to produce both direct and indirect effects on the host economies.

In this regard, the recent theoretical literature identifies several direct effects, but also indirect effects which include both horizontal and vertical spillovers. Horizontal spillovers correspond to technological externalities associated with specific knowledge, such as superior production techniques, know-how and management strategy. Since the associated rise in productivity takes place in the same industry, horizontal spillovers are often called intra-industry spillovers. ${ }^{2}$

Vertical productivity spillovers can be defined as pecuniary externalities due to FDI via backward and forward linkages to input markets. This can be the case when the MNE makes a transaction with local suppliers and customers and provides them technology transfer as well as know-how, which in turn improves the quality of intermediate products. Vertical externalities can also arise when the MNE raises its demand for local inputs as a backward linkage to intermediate good

\footnotetext{
${ }^{2}$ More precisely, Gorg and Strobl $(2000,2002)$ identify three channels for horizontal spillovers. The first corresponds to "demonstration effects" (as FDI leads to the imitation of advanced technology by local firms). The second reflects "labour turnover", i.e. the move of highly skilled workers from the MNE to local firms. The last channel denotes "competition effects": FDI induces an increased competition in the host country, as local firms are forced to use the existing technology more efficiently.
} 
suppliers. Thanks to the backward linkage mechanism, the productivity of domestic firms improves. Finally, vertical spillovers can also occur when domestic producers purchase more sophisticated intermediate goods from MNEs and thus increase their productivity via forward linkages. In any case, vertical spillovers involve several industries. As a result, they are called "inter-industry" spillovers.

Surprisingly, there is little theoretical work on vertical spillovers. Markusen and Venables (1999) develop a model which focuses on demand creation effects on the host economy. In this model, the entry of MNEs leads to an increased demand for intermediate goods in the host economy. To show that, it is assumed that two monopolistic competitive industries are linked through an input-output structure. The key variable is the input-output coefficient which measures the linkage back to the producers of intermediate goods. The result shows that this backward linkage is strong so long as multinationals use intermediate goods more intensively than domestic firms.

Lin and Saggi (2005) explore the supply-side effects of multinational entries on local suppliers. They focus on the relationship between technology transfers from multinationals to local suppliers and the degree of backward linkages. To that end, they build up a simple model which includes horizontal and vertical technology transfers into a two-tier oligopolistic structure. The results show that the entry of MNEs increases the degree of backward linkages in the host economy so long as the technology transfer advantage in final goods is not too large over its local competitors.

Although these two models provide a strong theoretical support for the idea that FDI can play a crucial role in productivity spillovers through backward linkages to the host economy, they do not explore the forward linkages between upstream and downstream industries. The model presented here fills this lack of literature by investigating simultaneously backward and forward linkages. We start modeling complex multinational activities in a Knowledge-Capital model, following Baltagi and al. (2007). From this model, we explore the demand effect side of FDI like Markusen and Venables (1999), but extended to horizontal and vertical multinational activities (complex FDI) and related to both the upstream and the downstream industries.

We consider a model with two goods: homogeneous $(Y)$ and differentiated $(X)$; three countries: home $(i)$, host $(j)$ and foreign $(f)$ and four factors: physical capital $(K)$, skilled labour $(S)$ unskilled labour $(L)$ as well as intermediate input $(Z)$. In addition, there are three types of firms in the $\mathrm{X}$ industry: national $(n)$, horizontal 
MNE $(h)$ and vertical MNE (v). MNEs' headquarters in i serve their affiliates with physical capital and skilled labour. Homogeneous goods are produced with constant returns to scale and perfect competition by using unskilled labour only. Conversely, the production of the differentiated good uses the four factors, whereas intermediate goods are produced with scale economies by using skilled and unskilled labour. It is also assumed that both local and multinational firms operate in the downstream industry by using intermediate inputs from the local upstream industry.

We start by modeling a representative consumer in the host country. Assuming a Dixit and Stiglitz (1977) framework for homogenous and differentiated goods aggregated by a Cobb-Douglas function, we derive a utility function where consumer utility depends on the quantity of good $X$ consumed in the host country $(j)$ and produced by domestic firms, horizontal and vertical MNE as well as the quantity of good $X$ produced in the home and the foreign country (i and f). It also depends on the quantity of good $Y$ produced in each country.

$$
U_{j}=\left[\begin{array}{c}
\eta_{j} X_{j}^{\frac{\varepsilon-1}{\varepsilon}}+\eta_{h} X_{h}^{\frac{\varepsilon-1}{\varepsilon}}+\eta_{v} X_{v}^{\frac{\varepsilon-1}{\varepsilon}}+\eta_{i}\left(\frac{X_{j}}{\left(1+t_{i j}\right)\left(1+\tau_{i j}\right)}\right)^{\frac{\varepsilon-1}{\varepsilon}} \\
+\eta_{f}\left(\frac{X_{f}}{\left(1+t_{f j}\right)\left(1+\tau_{f j}\right)}\right)^{\frac{\varepsilon-1}{\varepsilon}}\left[Y_{j}+Y_{i}+Y_{f}\right]^{1-\alpha}
\end{array}\right]^{\varepsilon-1}
$$

$\alpha$ is the Cobb Douglas expenditure share for differentiated products, $\varepsilon>1$ is the elasticity of substitution between varieties, $\eta$ is the number of firms, $t$ and $t$ denotes iceberg transport costs and tariff rates, respectively.

After maximizing the utility function subject to a budget constraint, product market clearing equations are given by:

$$
\begin{gathered}
X_{j} \geq p_{j}^{-\varepsilon} I_{j}^{\varepsilon-1} \alpha M_{j} \perp p_{j} \geq 0 \\
X_{h} \geq p_{j}^{-\varepsilon} I_{j}^{\varepsilon-1} \alpha M_{j} \perp p_{h} \geq 0 \\
X_{v} \geq p_{v}^{-\varepsilon} I_{j}^{\varepsilon-1} \alpha M_{j} \perp p_{v} \geq 0 \\
X_{i} \geq p_{i}^{-\varepsilon}\left(\left(1+t_{i j}\right)\left(1+\tau_{i j}\right)\right)^{1-\varepsilon} I_{j}^{\varepsilon-1} \alpha M_{j}
\end{gathered}
$$




$$
\begin{gathered}
X_{f} \geq p_{f}^{-\varepsilon}\left(\left(1+t_{i j}\right)\left(1+\tau_{i j}\right)\right)^{1-\varepsilon} I_{j}^{\varepsilon-1} \alpha M_{j} \\
Y_{j}+Y_{i}+Y_{f} \geq \frac{(1-\alpha) M_{j}}{q_{j}} \perp q_{j} \geq 0
\end{gathered}
$$

where $\perp$ indicates that at least one of the adjacent conditions has to hold with the inequality. $M_{j}$ denotes the income (and expenditure) of the representative consumer in $j ; p$ reflects the price of X-varieties, and $q$ refers to the price of Y-goods. Since all the homogeneous goods consumed at one location must face the same price, $q_{j}$ is the price of the homogeneous goods consumed in $j . p_{j}, p_{h}$ and $p_{v}$ are the prices of the differentiated goods produced in $j$ by the domestic firm as well as by the horizontal and vertical MNEs respectively, while $p_{i}$ and $p_{f}$ are the prices of the differentiated goods produced in $i$ and $f$ respectively. The price of goods $X$ originating from $i$ exported to $j$ amounts to $p_{i}\left(1+t_{i j}\right)\left(1+t_{i j}\right)$. Identically, the price of goods $X$ originating from $\mathrm{f}$ exported to $j$ amounts to $p_{f}\left(1+t_{f j}\right)\left(1+t_{f j}\right)$. The price index of the differentiated varieties $(I)$ consumed in country $j$ can be written as:

$$
\begin{aligned}
I_{j}^{1-\varepsilon}= & \eta_{j} p_{j}^{1-\varepsilon}+\eta_{h} p_{h}^{1-\varepsilon}+\eta_{v} p_{v}^{1-\varepsilon}+\eta_{i}\left(p_{i}\left(1+t_{i j}\right)\left(1+\tau_{i j}\right)\right)^{1-\varepsilon} \\
& \eta_{f}\left(p_{f}\left(1+t_{f_{j}}\right)\left(1+\tau_{f j}\right)\right)^{1-\varepsilon}
\end{aligned}
$$

On the supply side, we assume that the host country producers of the differentiated good purchase the intermediate goods from local firms by using skilled and unskilled labour under economies of scale. The intermediate goods are only supplied domestically and are non-tradable. The cost function for the production of $X$ using the four inputs is the following:

$$
c_{j}=K_{j} w_{K j}+S_{j} w_{S j}+L_{j} w_{L j}+Z_{j} p_{Z j}
$$

where $w_{K j}$ is the rental rate for capital in $j, w_{S j}$ and $w_{L j}$ are the wage rates for skilled and unskilled labour in $j$, and $p_{Z j}$ is the price of the intermediate input derived from the demand for intermediate good in country $j$ (Appendix A).

The production of the differentiated $\operatorname{good} X$ in $j$ for local and foreign markets is given by a nested CES production function:

$$
Y_{X j}(K, S, L, Z)=\phi\left[a K_{j}^{\frac{\varepsilon-1}{\varepsilon}}+b S_{j}^{\frac{\varepsilon-1}{\varepsilon}}+c L_{j}^{\frac{\varepsilon-1}{\varepsilon}}+d Z_{j}^{\frac{\varepsilon-1}{\varepsilon}}\right]^{\frac{\varepsilon}{\varepsilon-1}}
$$

With $a+b+c+d=1$ and $\varepsilon>1$ reflects the elasticity of substitution between inputs. 
$\mathrm{K}, \mathrm{S}$ and $\mathrm{L}$ are the quantities of capital, skilled and unskilled labour used for production, whereas $\mathrm{Z}$ is the CES aggregate of intermediate inputs (Appendix A). Factor demand for differentiated goods is derived from the production by using a standard Lagrange optimization approach:

$$
L=K_{j} w_{K j}+S_{j} w_{S j}+L_{j} w_{L j}+Z_{j} p_{Z j}+\lambda\left(Y_{X j}-\phi\left[a K_{j}^{\frac{\varepsilon-1}{\varepsilon}}+b S_{j}^{\frac{\varepsilon-1}{\varepsilon}}+c L_{j}^{\frac{\varepsilon-1}{\varepsilon}}+d Z_{j}^{\frac{\varepsilon-1}{\varepsilon}}\right]^{\frac{\varepsilon}{\varepsilon-1}}\right)
$$

The first order conditions are:

$$
\begin{gathered}
\frac{\partial L}{\partial K_{j}}=w_{K j}-\lambda \phi a K_{j}^{-\frac{1}{\varepsilon}}\left(a K_{j}^{\frac{\varepsilon-1}{\varepsilon}}+b S_{j}^{\frac{\varepsilon-1}{\varepsilon}}+c L_{j}^{\frac{\varepsilon-1}{\varepsilon}}+d Z_{j}^{\frac{\varepsilon-1}{\varepsilon}}\right)^{\frac{1}{1-\varepsilon}}=0 \\
\frac{\partial L}{\partial S_{j}}=w_{S j}-\lambda \phi a S_{j}^{-\frac{1}{\varepsilon}}\left(a K_{j}^{\frac{\varepsilon-1}{\varepsilon}}+b S_{j}^{\frac{\varepsilon-1}{\varepsilon}}+c L_{j}^{\frac{\varepsilon-1}{\varepsilon}}+d Z_{j}^{\frac{\varepsilon-1}{\varepsilon}}\right)^{\frac{1}{1-\varepsilon}}=0 \\
\frac{\partial L}{\partial L_{j}}=w_{L j}-\lambda \phi c L_{j}^{-\frac{1}{\varepsilon}}\left(a K_{j}^{\frac{\varepsilon-1}{\varepsilon}}+b S_{j}^{\frac{\varepsilon-1}{\varepsilon}}+c L_{j}^{\frac{\varepsilon-1}{\varepsilon}}+d Z_{j}^{\frac{\varepsilon-1}{\varepsilon}}\right)^{\frac{1}{1-\varepsilon}}=0 \\
\frac{\partial L}{\partial L_{j}}=p_{Z j}-\lambda \phi c Z_{j}^{-\frac{1}{\varepsilon}}\left(a K_{j}^{\frac{\varepsilon-1}{\varepsilon}}+b S_{j}^{\frac{\varepsilon-1}{\varepsilon}}+c L_{j}^{\frac{\varepsilon-1}{\varepsilon}}+d Z_{j}^{\frac{\varepsilon-1}{\varepsilon}}\right)^{\frac{1}{1-\varepsilon}}=0 \\
\frac{\partial L}{\partial \lambda}=Y_{X j}-\phi\left[a K_{j}^{\frac{\varepsilon-1}{\varepsilon}}+b S_{j}^{\frac{\varepsilon-1}{\varepsilon}}+c L_{j}^{\frac{\varepsilon-1}{\varepsilon}}+d Z_{j}^{\frac{\varepsilon-1}{\varepsilon}}\right]^{\frac{\varepsilon}{\varepsilon-1}}=0
\end{gathered}
$$

Dividing (13), (14) et (15) by (12), we obtain:

$$
\begin{aligned}
& S_{j}=\left(\frac{a}{b} \frac{w_{S j}}{w_{K j}}\right)^{-\varepsilon} K_{j} \\
& L_{j}=\left(\frac{a}{c} \frac{w_{L j}}{w_{K j}}\right)^{-\varepsilon} K_{j} \\
& Z_{j}=\left(\frac{a}{d} \frac{p_{Z j}}{w_{K j}}\right)^{-\varepsilon} K_{j}
\end{aligned}
$$

Inserting (17), (18) and (19) into (16) makes it possible to obtain the demand for physical capital for the production of $\operatorname{good} X$ :

$$
K_{j}=Y_{X j} \frac{1}{\phi}\left[a+b H_{1 j}+c H_{2 j}+d H_{3 j}\right]^{\frac{\varepsilon-1}{\varepsilon}}=Y_{X j} a_{K X}
$$


where: $H_{1 j}=\left(\frac{a}{b} \frac{w_{S j}}{w_{K j}}\right)^{1-\varepsilon} ; H_{2 j}=\left(\frac{a}{c} \frac{w_{L j}}{w_{K j}}\right)^{1-\varepsilon} ; H_{3 j}=\left(\frac{a}{d} \frac{p_{Z j}}{w_{K j}}\right)$ and $a_{K X}$ is the country specific input coefficient for physical capital of good $X$ 's production. Inserting equation (20) into (17), (18) and (19), we derive the other factor demands for the production of good $X$ :

$$
\begin{aligned}
& S_{j}=Y_{X j} \frac{1}{\phi} H_{1 j}^{\frac{\varepsilon}{\varepsilon-1}}\left[a+b H_{1 j}+c H_{2 j}+d H_{3 j}\right]^{\frac{\varepsilon-1}{\varepsilon}}=Y_{X j} a_{S X} \\
& L_{j}=Y_{X j} \frac{1}{\phi} H_{2 j}^{\frac{\varepsilon}{\varepsilon-1}}\left[a+b H_{1 j}+c H_{2 j}+d H_{3 j}\right]^{\frac{\varepsilon-1}{\varepsilon}}=Y_{X j} a_{L X} \\
& Z_{j}=Y_{X j} \frac{1}{\phi} H_{3 j}^{\frac{\varepsilon}{\varepsilon-1}}\left[a+b H_{1 j}+c H_{2 j}+d H_{3 j}\right]^{\frac{\varepsilon-1}{\varepsilon}}=Y_{X j} a_{Z X}
\end{aligned}
$$

where $a_{S X}, a_{L X}$ and $a_{Z X}$ are the country specific input coefficients for skilled labour, unskilled labour and intermediate inputs (respectively).

As a final step, factor market clearing conditions which ensure all factors are fully employed in $X$-goods, $Y$-goods and $Z$-goods production for country $j$ can be derived as:

$$
\begin{gathered}
K_{j} \geq a_{K X}\left\lfloor\eta_{j} X_{j}+\eta_{h} X_{h}+\eta_{v} X_{v}\right\rfloor+\eta_{j} \perp w_{K j} \geq 0 \\
S_{j} \geq a_{S X}\left\lfloor\eta_{j} X_{j}+\eta_{h} X_{h}+\eta_{v} X_{v}\right\rfloor+a_{S Z}\left(\eta_{z j} Z_{j}\right)+\eta_{j} \perp w_{S j} \geq 0 \\
L_{j} \geq a_{L X}\left\lfloor\eta_{j} X_{j}+\eta_{h} X_{h}+\eta_{v} X_{v}\right\rfloor+a_{L Z}\left(\eta_{z j} Z_{j}\right)+Y_{j} \perp w_{L j} \geq 0 \\
Z_{j} \geq a_{Z X}\left\lfloor\eta_{j} X_{j}+\eta_{h} X_{h}+\eta_{v} X_{v}\right\rfloor \perp p_{Z j} \geq 0
\end{gathered}
$$

where $\mathrm{a}_{S Z}$ and $\mathrm{a}_{L Z}$ are country specific input coefficient for skilled and unskilled labor, respectively, of intermediate goods production. The variable unit costs of producing $X_{j}$ is given by:

$$
c_{X j}=a_{K X} w_{K j}+a_{S X} w_{S j}+a_{L X} w_{L j}+a_{Z X} P_{z j}
$$

In this model, the key equation for showing backward and forward linkages is 
equation (27), i.e. the intermediate good demand for goods $X$ in the host country. After maximizing profits given the demand for intermediate inputs used in producing good $X$ and the production of intermediate goods, we get zero profit function for an intermediate goods producer in $j$ :

$$
p_{Z j} Z_{j}=c_{Z j} a_{Z X}\left(\eta_{j} X_{j}+\eta_{h} X_{h}+\eta_{v} X_{v}\right)
$$

where $\mathrm{c}_{z j}$ is marginal cost of intermediate goods producer in country $j$. From equation (29), the model captures the forward and backward linkages between the downstream and the upstream industries. A rise in the demand of products in the upstream industry reduces the price of intermediate inputs and also lowers the production costs in the downstream industry. As a result, the spillover effect of FDI on the host economy can be summarized by the following proposition:

Proposition: The entry of multinational firms gives rise to spillover effects through backward linkages that expands the intermediate production in the upstream industry. This in turn gives rise to a decrease in the price of the downstream industry (good X), through forward linkages.

Proof: See Appendix

The logic behind this result is fairly simple: it is obvious that under certain conditions related to production, the entry of multinationals leads to a rise in the demand for intermediate goods in the upstream industry. This gives rise to an expansion of the intermediate industry and thus to a reduction in prices thanks to scale economies. This in turns makes possible the reduction in the price of $\operatorname{good} X$ and thus benefits the downstream industry. In sum, both the upstream and the downstream industries can take advantage of productivity spillovers due to the presence of MNEs. This result complements that of Markusen and Venables (1999) which focus on backward linkages only.

\section{An Empirical Model Applied to ASEAN Countries}

From an empirical point of view, there is extensive recent literature with regard to the relationship between FDI and productivity spillovers. Surprisingly, empirical results are often mixed. For example, in a recent survey of the empirical literature which concerns horizontal spillovers, Görg and Greenaway (2004) show that only 22 of the 40 studies investigated find positive spillover effects.

There is generally more empirical evidence for positive vertical spillover effects. 
For example, Blalock and Gertler (2003) look separately at both horizontal and vertical spillovers in Indonesia by using a semi-parametric estimation method. Using a panel dataset of Indonesian manufacturing, they find evidence of positive vertical spillovers through backward linkages, but also the absence of horizontal spillovers. Similar studies use the same technique, such as Smarzynska (2003) for Lithuania, Lopez-Cordova (2003) for Mexico, Blyde et al. (2004) for Venezuela as well as Jarvorcik and Spatareanu (2006) for Romania and Marcin (2008) for Poland. They all report evidence for positive vertical spillovers to local suppliers, conditional to backward linkages. However, Schoors and Tol (2002) and Sasidharan (2006) find negative vertical spillover effects for Hungary and India, respectively. Finally, Vahter and Masso (2007) as well as Mullen and Williams (2007) do not find any significant relationship between FDI and productivity for Estonia and the USA, respectively, whereas Girma and al. (2008) also find mixed results depending of the type of the FDI.

To sum up, there is still no clear evidence of positive productivity spillovers. This contradicts the recent theoretical developments. The main reason which is put forward to explain this difference between theoretical and empirical evidence is related to the quality of the data and the choice of the empirical technique. This is why recent studies attempt to refine and to improve the quality of the data and the econometric methodology.

Another characteristic of the empirical literature is the limitation of the number of studies concerning developing countries, including ASEAN countries. This is mainly due to the lack of data at firm-level. One way to avoid this problem is to focus on the causal relationship between FDI and productivity. Surprisingly, there is still a lack of literature in this field. So far, some studies have analysed the causality between FDI and economic growth (Zhang, 2001 and Choe, 2003), while $\mathrm{Ng}$ (2006) only examines the causality between FDI and productivity. ${ }^{3}$

The empirical model proposed here makes it possible to test the theoretical proposition developed in the previous section. In particular, using country-specific data instead of data at firm level makes it possible to capture the spillover effects of FDI outside the industry, i.e. vertical spillovers. Five ASEAN countries are considered empirically. These are Indonesia, Malaysia, Philippines, Singapore and Thailand over the period 1970-2005. These ASEAN-5 countries account for $93.1 \%$

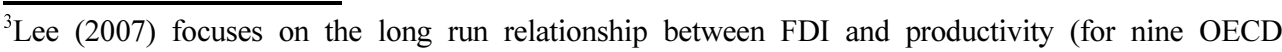
countries). However, the causality between the two variables has not been investigated. 
of overall FDI flows to ASEAN countries, as well as more than $95 \%$ of overall intra-ASEAN FDI. Another common characteristic of these countries is that they all signed the trade and investment agreements (CEPT and AIA) first. As a result, these agreements were implemented in these countries first before their extension to the other less developed ASEAN countries. Data on FDI and productivity are derived from the UNCTAD FDI database and the World Bank World Development Indicator database.

The causality analysis is carried out on two variables, namely the FDI as a proportion of GDP as well as total factor productivity (TFP). The latter is estimated by using the Solow growth accounting framework, which consistently decomposes GDP growth into the growth in physical capital stock per worker, human capital per worker as well as growth in TFP (see for example Sarel (1997) for an application to ASEAN countries). Data on capital and labour are derived from the World Bank's Development indicators.

Table 2. Unit Root Tests for the TFP and FDI

\begin{tabular}{|c|c|c|c|c|c|c|}
\hline \multirow{2}{*}{ Country } & \multicolumn{6}{|c|}{$\ln \mathrm{FDI}$} \\
\hline & $\mathrm{ADF}$ & PP & KPSS & ERS & DF-GLS & NP \\
\hline Indonesia & $-2.467^{\alpha}$ & $-2.457^{\circ}$ & 0.115 & $-2.723^{a}$ & $-10.142^{\#}$ & $-9.953^{\#}$ \\
\hline Malaysia & $-5.039^{*}$ & $-5.049^{*}$ & 0.059 & $-5.164^{*}$ & $5.262^{* *}$ & $-17.300^{* *}$ \\
\hline Philippines & $-3.505^{* *}$ & $-3.419^{\dagger}$ & 0.124 & $-3.608^{* *}$ & $4.452^{* *}$ & $-20.319^{* *}$ \\
\hline Singapore & $-6.267^{*}$ & $-6.267^{*}$ & 0.113 & $-6.337^{*}$ & $5.184^{* *}$ & $-17.312^{* *}$ \\
\hline Thailand & $-6.415^{*}$ & $-6.412^{*}$ & 0.114 & $-6.412^{*}$ & $5.335^{* *}$ & $-17.236^{\dagger}$ \\
\hline ASEAN-5 & $-12.601^{*}$ & $12.601^{*}$ & 0.071 & $-12.616^{*}$ & $1.085^{*}$ & $-83.462^{\dagger}$ \\
\hline \multirow{2}{*}{ Country } & \multicolumn{6}{|c|}{$\ln (\mathrm{FDI} / \mathrm{GDP})$} \\
\hline & $\mathrm{ADF}$ & PP & KPSS & ERS & DF-GLS & NP \\
\hline Indonesia & -2.756 & $-1.56^{\circ}$ & 0.131 & -1.631 & 162.79 & $-3443.6^{*}$ \\
\hline Malaysia & $-4.551^{*}$ & $-3.150^{a}$ & 0.085 & $-3.218^{* *}$ & $2670.0^{\infty \alpha}$ & $-12.495^{\#}$ \\
\hline Philippines & $-4.487^{*}$ & $-4.481^{*}$ & 0.130 & $-4.627^{*}$ & $5.312^{* *}$ & $-16.223^{* *}$ \\
\hline Singapore & $-4.295^{*}$ & $-4.444^{*}$ & 0.130 & $-4.409^{*}$ & 20.515 & $-16.225^{\dagger}$ \\
\hline Thailand & $-4.551^{*}$ & $-3.133^{\dagger}$ & 0.101 & $-3.062^{\dagger}$ & $1.579^{*}$ & $-11.620^{\infty}$ \\
\hline ASEAN-5 & $-3.802^{* *}$ & $-3.963^{* *}$ & 0.080 & $-3.345^{* *}$ & $3.983^{*}$ & $-17.887^{* *}$ \\
\hline
\end{tabular}

Notes: a) The superscripts $*, * *$ and ${ }^{\dagger}$ indicate statistical significance at $1 \%, 5 \%$ and $10 \%$ level, respectively.

b) The superscript ${ }^{\infty}$ and ${ }^{\#}$ indicate that the data is integrated of order zero $\mathrm{I}(0)$ in the first difference at $1 \%, 5 \%$ and $10 \%$ level of significance, respectively.

c) The lag length in the ADF and DF-GLS test is chosen by the Akaike Information Criterion (AIC). The PP and KPSS test bandwidth selection is based on Newey and West (1994) using the spectral density at frequency zero with a Bartlett kernel. The lag length in the ERS point optimal and NP tests is chosen using the spectral GLS-detrended based on the AIC and the spectral GLS-detrended based on the modified AIC, respectively. 
Before exploring the causality links between FDI and TFP, preliminary tests are performed in order to explore the data univariate properties and to determine the degree of integration of the series. For that purpose, unit root tests and cointegration tests are implemented.

Looking first at unit root tests (Table 2), several alternative tests have been applied as a sensitivity analysis. These are the Augmented Dickey-Fuller (ADF), the Phillips-Perron (PP), the Kwiatkowski-Phillips-Shin (KPSS), the ElliotRothenberg-Stock (ERS) point optimal as well as the Ng-Perron (NP) tests. All these tests have been implemented by using levels or alternatively first differences of FDI and TFP time series.

Results generally suggest that for most economies, the TFP growth is stationary in level or integrated of order zero. The only exception is Indonesia where the TFP growth is not stationary in level but in first difference. Results are less straightforward concerning FDI, for which traditional and newly developed unit root tests sometimes give conflicting results, with the exception of Philippines.

To sum up, the tests indicate that for the Philippines, the FDI and TFP series are stationary. In the case of Malaysia, Singapore and Thailand, the TFP and FDI series are not cointegrated, since they are not integrated of the same order. With regard to Indonesia, the two series are found to be integrated of order one, after using appropriate tests (see also Table 9 for a summary). ${ }^{4}$ As a result, cointegration tests have to be implemented to determine the existence of a long run equilibrium relationship among these two variables. In this regard, both the Johansen cointegration test and the Engle-granger two-step cointegration test support the hypothesis of cointegration between TFP and FDI, suggesting a long run relationship between these two variables (see Tables $3 a$ and $3 b$ ).

Table 3a. Johansen Cointegration Test Results for the TFP and FDI (Indonesia)

\begin{tabular}{cccccc}
\hline $\begin{array}{c}\text { Null } \\
\text { Hypothesis }\end{array}$ & Eigenvalue & $\begin{array}{c}\text { Trace } \\
\text { Statistic }\end{array}$ & $\begin{array}{c}5 \% \text { Critical } \\
\text { value }\end{array}$ & $\begin{array}{c}\text { Maximum } \\
\text { Eigenbalue }\end{array}$ & $\begin{array}{c}5 \% \text { Critical } \\
\text { value }\end{array}$ \\
\hline $\mathrm{r}=0$ & 0.865 & 33.824 & 25.872 & 28.000 & 19.387 \\
$\mathrm{r} \leq 1$ & 0.340 & 5.824 & 12.518 & 5.824 & 12.518 \\
\hline
\end{tabular}

Notes: a) Cointegration test is based on a linear deterministic trend (restricted) assumption.

b) The term $r$ is the number of cointegration vectors under the null hypothesis.

c) Both trace and maximum eigenvalue tests imply significance at $5 \%$ level.

${ }^{4}$ The alternative tests used for optimal lag length determination are the Aikaike Information Criterion (AIC), the Schwarz Bayesian Information Criterion (SIC), the Hannan-Quinn Information criterion (HQ), the Final Prediction Error (FPE) as well as the Likelihood ratio (LR). 
Table 3b. Engle-Granger Two-step Cointegration Test Results for TFP and FDI (Indonesia)

\begin{tabular}{cccc}
\hline Cointegration Equation & ADF t-statistic & Adj $^{2}$ & Durbin-Watson Statistic \\
\hline $\ln \mathrm{TFP}=\mathrm{f}(\ln \mathrm{FDI})$ & -0.937 & 0.213 & 0.322 \\
$\ln \mathrm{FDI}=\mathrm{f}(\ln \mathrm{TFP})$ & $-10.143^{* *}$ & 0.970 & 1.713 \\
\hline
\end{tabular}

The last step concerns the investigation of the causal relationship between FDI and TFP growth. Two approaches are considered here as a sensitivity analysis. The first approach corresponds to the standard Granger causality test. This test requires precise information about the characteristics of the time series. In the present paper, these characteristics differ across countries. Indeed, as already explained, three cases must be considered: the first applies when both series are I(0) (Philippines). In this case, the standard Granger causality test can be applied. The second case refers to Malaysia, Singapore and Thailand, where one of the series is $I(0)$ and the other is I(1). Since these series are not cointegrated, the Granger causality test in first difference is applied. The last case corresponds to Indonesia, where both series are I(1) and cointegrated. Here, a Granger causality test on an Error Correction Model (ECM) can be applied.

The second approach corresponds to a direct approach of the Granger causality test, developed by Toda and Yamamoto (1995). One crucial advantage is that this test can be performed whatever the properties of the series, i.e. stationary, cointegrated or not cointegrated. Therefore, results are not sensitive to unit roots and cointegration tests, as the standard granger causality tests are. In fact, prior the implementation of the Toda and Yamamoto test, we only need to establish the optimal lag length of the system $(k)$ and the maximum order of integration of the variables $\left(d_{\max }\right)$. We then estimate the VAR of the TFP growth and FDI for each country, using a number of $k+d_{\max }$ lags. The Wald test is used to check whether the coefficients of the lagged variables are significantly different from zero. The corresponding chi-square statistics can be compared to the estimated p-values in order to determine the existence of causality.

Results are presented in Tables 4 to 7. It is striking to observe that the indirect approach provides limited support to the causality between FDI and TFP growth. In fact, Singapore only is concerned by this result. Similarly, the reversed causality, i.e. between TFP and FDI is also mixed, with evidence that TFP causes FDI for Malaysia and Indonesia only.

In contrast, the Toda-Yamamoto test (Table 7) gives strong evidence that FDI causes TFP growth for all countries. This result correlates with our theoretical 
Table 4. Standard Granger Causality Test Results for TFP and FDI (Philippines)

\begin{tabular}{lcccc}
\hline \multicolumn{1}{c}{ Null Hypothesis $\left(\mathrm{H}_{0}\right)$} & VAR & MWald Statistics & p-value & Results \\
\hline Philippines & & & & \\
FDI no GRanger cause TFP & 1 & 0.155 & 0.696 & Accept \\
TFP no Granger cause FDI & 1 & 0.007 & 0.933 & Accept \\
ASEAN-5 & 3 & 5.227 & 0.001 & Reject \\
FDI no GRanger cause TFP & 3 & 0.308 & 0.819 & Accept \\
TFP no Granger cause FDI &
\end{tabular}

Note: The p-value statistics indicate a statistical significance at $5 \%$ level.

Table 5. Granger Causality Test Results in First Differences for TFP and FDI

\begin{tabular}{lcccc}
\hline Null Hypothesis $\left(\mathrm{H}_{0}\right)$ & VAR & MWald Statistics & p-value & Results \\
\hline Malaysia & & & & \\
$\Delta$ FDI no Granger cause TFP & 3 & 0.465 & 0.710 & Accept \\
TFP no Granger cause $\Delta$ FDI & 3 & 1.970 & 0.144 & Reject \\
Singapore & 1 & 0.538 & 0.469 & Reject \\
$\Delta$ FDI no Granger cause TFP & 1 & 0.013 & 0.909 & Accept \\
TFP no Granger cause $\Delta$ FDI & 1 & 0.086 & 0.771 & Accept \\
Thailand & 1 & 0.135 & 0.716 & Accept \\
$\Delta$ FDI no Granger cause TFP & 1 & &
\end{tabular}

Note: The p-value statistics indicate a statistical significance at $5 \%$ level.

Table 6. Estimation Results of the ECM for TFP and FDI (Indonesia)

\begin{tabular}{lcccc}
\cline { 2 - 4 } & \multicolumn{2}{c}{$\mathrm{EC}_{\mathrm{t}-1}$} & \multicolumn{2}{c}{ Lagged value } \\
\cline { 2 - 5 } & coefficient & t-statistic & coefficient & F-statistic \\
\hline Indonesia & 0.048 & 0.609 & -0.292 & -0.509 \\
$\Delta \ln$ FDI on $\Delta \ln$ TFP & 0.255 & $2.503^{* *}$ & -3.422 & $-2.625^{* *}$ \\
\hline $\ln$ TFP on $\Delta \ln$ FDI & &
\end{tabular}

Note: ${ }^{* *}$ denotes statistically significant at $5 \%$ level of significance.

prediction provided in the previous section, which states that multinational enterprises give rise to productivity spillover effects. In addition, the TodaYamamoto test also indicates that TFP growth causes FDI, except for Indonesia and Singapore. This means that, except for these two countries, there is a bidirectional causality between the two variables.

Again, these differences in the results obtained by the Standard Granger test and the Toda-Yamamoto are likely to be explained by the sensitivity of the indirect approach to unit root and cointegration tests. This is why the direct approach is preferred here. As a last sensitivity analysis, some robustness checks are carried out 
Table 7. Toda-Yamamoto Granger Causality Test Results for TFP and FDI

\begin{tabular}{|c|c|c|c|c|}
\hline Null Hypothesis $\left(\mathrm{H}_{0}\right)$ & $\operatorname{VAR}\left(\mathrm{k}+\mathrm{d}_{\max }\right)$ & MWald Statistics & p-value & Results \\
\hline \multicolumn{5}{|l|}{ Indonesia } \\
\hline FDI no Granger cause TFP & 2 & 1.159 & 0.560 & Reject \\
\hline TFP no Granger cause FDI & 2 & 0.604 & 0.739 & Accept \\
\hline \multicolumn{5}{|l|}{ Malaysia } \\
\hline FDI no Granger cause TFP & 4 & 3.175 & 0.529 & Reject \\
\hline TFP no Granger cause FDI & 4 & 13.140 & 0.009 & Reject \\
\hline \multicolumn{5}{|l|}{ Philippines } \\
\hline FDI no Granger cause TFP & 2 & 2.340 & 0.311 & Reject \\
\hline TFP no Granger cause FDI & 2 & 1.132 & 0.568 & Reject \\
\hline \multicolumn{5}{|l|}{ Singapore } \\
\hline FDI no Granger cause TFP & 2 & 1.376 & 0.503 & Reject \\
\hline TFP no Granger cause FDI & 2 & 0.390 & 0.823 & Accept \\
\hline \multicolumn{5}{|l|}{ Thailand } \\
\hline FDI no Granger cause TFP & 2 & 0.966 & 0.617 & Reject \\
\hline TFP no Granger cause FDI & 2 & 1.039 & 0.595 & Reject \\
\hline \multicolumn{5}{|l|}{ ÁSEĀ } \\
\hline FDI no Granger cause TFP & 4 & 19.009 & 0.001 & Reject \\
\hline TFP no Granger cause FDI & 4 & 1.380 & 0.847 & Reject \\
\hline
\end{tabular}

Note: The p-value statistics indicate a statistical significance at $5 \%$ level.

Table 8. Robustness Checks for the Toda-Yamamoto Granger Causality Test

\begin{tabular}{|c|c|c|c|c|c|c|}
\hline & \multicolumn{3}{|c|}{ Type 1 and 2} & \multicolumn{3}{|c|}{ Type 3} \\
\hline & $\mathrm{p}$ & MWald & Results & $\mathrm{p}$ & MWald & Results \\
\hline \multicolumn{7}{|l|}{ Indonesia } \\
\hline FDI no Granger cause TFP & 3 & $2.795^{* *}$ & Reject & 4 & $1.499^{* *}$ & Reject \\
\hline TFP no Granger cause FDI & 3 & $10.843^{* *}$ & Reject & 4 & $12.384^{* *}$ & Reject \\
\hline \multicolumn{7}{|l|}{ Malaysia } \\
\hline FDI no Granger cause TFP & 5 & $11.363^{* *}$ & Reject & 6 & $2.366^{* *}$ & Reject \\
\hline TFP no Granger cause FDI & 5 & $2.988^{* *}$ & Reject & 6 & $19.597^{* *}$ & Reject \\
\hline \multicolumn{7}{|l|}{ Philippines } \\
\hline FDI no Granger cause TFP & 3 & $3.860^{* *}$ & Reject & 4 & $6.118^{* *}$ & Reject \\
\hline TFP no Granger cause FDI & 3 & $1.447^{* *}$ & Reject & 4 & $1.514^{* *}$ & Reject \\
\hline \multicolumn{7}{|l|}{ Singapore } \\
\hline FDI no Granger cause TFP & 3 & $\begin{array}{l}1.680 \\
0.966^{* *}\end{array}$ & Reject & 4 & $4.600^{* *}$ & Reject \\
\hline TFP no Granger cause FDI & 3 & & Reject & 4 & $2.398^{* *}$ & Reject \\
\hline \multicolumn{7}{|l|}{ Thailand } \\
\hline FDI no Granger cause TFP & 3 & $0.953^{* *}$ & Reject & 4 & $0.983^{* *}$ & Reject \\
\hline TFP no Granger cause FDI & 3 & $4.670^{* *}$ & Reject & 4 & $4.792^{* *}$ & Reject \\
\hline \multicolumn{7}{|l|}{ ASEAN } \\
\hline FDI no Granger cause TFP & 5 & $20.470^{* *}$ & Reject & 6 & $27.814^{* *}$ & Reject \\
\hline TFP no Granger cause FDI & 5 & $1.901^{* *}$ & Reject & 6 & $3.978^{* *}$ & Reject \\
\hline
\end{tabular}

Notes: a) Type 1, 2 and 3 denote the Toda-Yamamoto test with the number of lag length (p) at $\mathrm{k}+(\mathrm{dmax}+1),(\mathrm{k}+1)+\mathrm{dmax}$ and $(\mathrm{k}+1)+(\mathrm{dmax}+1)$ respectively.

b) ${ }^{* *}$ denotes statistically significant at $5 \%$ level of significance. 
Table 9. Main Results of the Tests

\begin{tabular}{cccccc}
\hline & TFP & FDI & Cointegration & Direct Causality & Indirect Causality \\
\hline Indonesia & $\mathrm{I}(1)$ & $\mathrm{I}(1)$ & $\sqrt{ }$ & $\mathrm{T}-\mathrm{Y}$ & $\mathrm{ECM}$ \\
Malaysia & $\mathrm{I}(0)$ & $\mathrm{I}(1)$ & $\times$ & $\mathrm{T}-\mathrm{Y}$ & $\mathrm{F}$ \\
Philippines & $\mathrm{I}(0)$ & $\mathrm{I}(0)$ & $\times$ & $\mathrm{T}-\mathrm{Y}$ & $\mathrm{S}$ \\
Singapore & $\mathrm{I}(0)$ & $\mathrm{I}(1)$ & $\times$ & $\mathrm{T}-\mathrm{Y}$ & $\mathrm{F}$ \\
Thailand & $\mathrm{I}(0)$ & $\mathrm{I}(1)$ & $\times$ & $\mathrm{T}-\mathrm{Y}$ & $\mathrm{F}$ \\
ASEAN-5 & $\mathrm{I}(0)$ & $\mathrm{I}(0)$ & $\times$ & $\mathrm{T}-\mathrm{Y}$ & $\mathrm{S}$
\end{tabular}

Note : $\mathrm{I}(0)$ = stationary, $\mathrm{I}(1)=$ unit root, $\mathrm{T}-\mathrm{Y}=$ Toda-Yamamoto Granger Causality Test, $\mathrm{S}=$ Standard Granger Causality Test, F = Granger Causality Test in First Differences, ECM = Granger Causality Test on Error Correction Model

with regard to the number of lagged lengths and the maximum order of integration $\left(k+d_{\max }\right)$ chosen in the Toda-Yamamoto test. Table 8 provides three types of alternative estimation. Type 1: the lag length is $k$ and $d_{\max }=2$; Type 2: the lag length is is $k+1$ and $d_{\max }=1$; Type 3: the lag length is $k+1$ and $d_{\max }=2$. From this table, in all three types of robustness checks, FDI is found to cause TFP at the 5\% level for all countries. This confirms the findings of Table 7 about productivity spillovers due to FDI.

\section{Conclusion and Policy Implications}

This article investigates the existence of productivity spillovers due to FDI in ASEAN countries. The theoretical model strongly supports this hypothesis, by showing that the entry of multinational firms gives rise to productivity spillovers through both backward and forward linkages. This theoretical prediction is supported by the Toda-Yamamoto causality test for all the ASEAN countries investigated.

These results have strong policy implications. Indeed, the recent efforts of ASEAN countries in terms of regional integration and FDI liberalization are likely to have contributed to the tremendous increase in both intra and extra FDI flows in the ASEAN area. This means that in addition to direct effects on the domestic economy (in terms of employment, production and trade), this surge in FDI is likely to give rise to strong indirect effects, especially productivity spillovers which strengthen the profitability and the competitiveness of the domestic economy.

The present work is still limited by the lack of data at firm level, as well as by the unavailability of quarterly or monthly data which could be helpful to 
investigate with more accuracy the FDI spillover effects. In particular, it is still too early to separate the precise impact of FDI growth which occurred after the 1997 crisis period from the previous period. This is left for future research.

Received 21 Nobember 2009, Revised 25 January 2010, Accepted 29 January 2010

\section{References}

ASEAN Secretariat (1998), "Framework Agreement on the ASEAN Investment Area", [online], at http://www.aseansec.org/6466.htm.

ASEAN Secretariat (2003), "Declaration of ASEAN Concord 2 (Bali Concord 2)", [online], at http://www.aseansec.org/15159.htm.

ASEAN Secretariat (2007a), "Cebu Declaration on the Acceleration of the Establishment of an ASEAN Community by 2015", [online], at http://www.aseansec.org/ 19260.htm.

ASEAN Secretariat (2007b), "Tenth ASEAN Investment Area (AIA) Council Meeting Joint Media Statement", [online], at http://www.aseansec.org/20834.htm.

ASEAN Secretariat (2008a), "Joint Media Statement of the Fortieth ASEAN Economic Ministers' (AEM) Meeting", [online], at http://www.aseansec.org/21833.htm.

ASEAN Secretariat (2008b), "Highlights on the ASEAN Comprehensive Investment Agreement", [online], at http://www.aseansec.org/21885.htm.

ASEAN Secretariat (2008c), "Statistics of Foreign Direct Investment in ASEAN", Ninth edition, [online], at http://www.aseansec.org/21402.htm

Baltagi, B, P. Egger and M. Pfaffermayr (2007), "Estimating Models of Complex FDI: Are there Third Country Effects?", Journal of Econometrics, Vol. 140, pp. 260-281.

Blalock, G. and P. Gertler (2003), "Technology from Foreign Direct Investment and Welfare Gains through the Supply Chain", Technical report, Cornell University and University of California.

Blyde, J., M. Kugler, and E. Stein (2004), "Exporting vs. Outsourcing by MNC Subsidiaries: Which Determines FDI Spillovers?", Discussion Papers in Economics and Econometrics 0411, University of Southampton.

Choe, J. (2003), "Do Foreign Direct Investment and Gross Domestic Investment Promote Economic Growth?", Review of Development Economics, Vol. 7, pp. 44-57.

Dixit, A. K. and J. E. Stiglitz (1977), "Monopolistic Competition and Optimum Product Diversity", American Economic Review, Vol. 67, pp. 297-308.

Girma, S., H. Görg and P. Holger (2008), "Linkages and Productivity Spillovers from Foreign Direct Investment”, Canadian Journal pf Economics, Vol. 41, pp. 320-340.

Görg, H. and D. Greenaway (2004) "Much Ado about Nothing? Do Domestic Firms Benefit from Foreign Direct Investment?", World Bank Research Observer, Vol. 19, pp. 171-197.

Görg, H. and E. Strobl (2000), "Multinational Companies and Productivity Spillovers: A 
Meta-Analysis with a Test for Publication Bias", Research Paper 2000/17, Centre for Research on Globalisation and Labour Markets, University of Nottingham.

Görg, H. and E. Strobl (2002), "Spillovers from Foreign Firms through Worker Mobility: An Empirical Investigation”, Research Paper 2002/13, Leverhulme Centre for Research on Globalisation and Economic Policy.

Habito, C., F. Aldaba and O. Templo (2004), "An Assessment Study on the Progress of ASEAN Regional Integration: The Hanoi Plan of Action toward ASEAN Vision 2020", REPSF project 03/006b, Ateneo Center for Economic Research and Development.

Javorcik, B. S. and M. Spatareanu (2006), "To Share or Not to Share: Does Local Participation Matter for Spillovers from Foreign Direct Investment?", Newark Working Paper 2006-001, Rutgers University.

Lee, G. (2007), "Long Run Equilibrium Relationship between FDI and Productivity", Journal of Economic Development, Vol. 32, pp. 183-192.

Lin, P. and K. Saggi (2005), "Does Foreign Direct Investment Promote Development? Chapter Multinational Firms and Backward Linkages: A Critical Survey and a Simple Model", Institute for International Economics, Washington D.C. pp. 159-174.

Lopez-Cordova, J. E. (2003), "NAFTA and Mexico's Manufacturing Productivity in Mexico", Technical Report 1, Inter-American Development Bank, Washingto D.C.

Markusen, J. R. and A. J. Venables (1999), "Foreign Direct Investment as a Catalyst for Industrial Development", European Economic Review, Vol. 43, pp. 335-356.

Marcin, K. (2008), "How Does FDI Inflows Affect Productivity of Domestic Firms? The Role of Horizontal and Vertical Spillovers, Absorptive Capacity and Competition", Journal of International Trade and Economic Development, Vol. 17(1), pp.155-173.

Mullen, J. and M. Williams (2007), "Foreign Direct Investment and Regional Productivity Spillovers in US Manufacturing", Review of Urban and Regional Development Studies, Vol. 19(3), pp. 185-196.

Navaretti, G. and J. Venables (2004), Multinational Firms in the World Economy, Princeton: Princeton University Press.

Ng, T. (2006), "Foreign Direct Investment and Productivity: Evidence from the East Asian Economies", UNIDO, Staff Working Paper 03/2006, United Nations Industrial Development Organization.

Sarel, M. (1997), "Growth and Producticity in ASEAN countries", IMF Working Paper, WP 97/97, International Monetary Fund.

Sasidharan, S. (2006), "Foreign Direct Investment and Technology Spillovers: Evidence from the Indian Manufacturing sector", Working paper series, 2006-010, United Nations Univesity.

Schoors, K. and B. V. D. Tol (2002), "Foreign Direct Investment Spillovers Within and Between Sectors: Evidence from Hungarian Data”, Working Paper 2002/157, Ghent University, Belgium.

Smarzynska, B. K. (2003), "Does Foreign Direct Investment Increase the Productivity of Domestic Firms?", in: Search of spillovers through Backward Linkages, William 
Davidson Working Paper 548, the William Davidson Institute.

Toda, H. and T. Yamamoto (1995), "Statistical Inference in Vector Autoregressions with

Possibly Integrated Processes", Journal of Econometrics, Vol. 66, pp. 225-250.

Vahter, P. and J. Masso (2007), "Home versus Host Country Effects of FDI: Searching for

New Evidence of Productivity Spillovers", Applied Economics Quarterly, Vol. 53, pp. 165-196.

Zhang, K. (2001), "Does Foreign Direct Investment Promote Economic Growth?

Evidence from East Asia and Latin America", Contemporary Economic Policy, Vol.

19, pp. 175-185.

\section{Appendix}

\section{A. Intermediate Goods Sector}

Demand for intermediate goods in country $j$ is derived via the maximization of the utility function for intermediate goods aggregated by a Cobb-Douglas function:

$$
Z_{X j}=\left[\sum_{j=1}^{3} \eta_{Z j}\left(Z_{j}\right)^{\frac{\varepsilon-1}{\varepsilon}}\right]^{\frac{\varepsilon}{\varepsilon-1}} \quad \text { s.t. }\left[\sum_{j=1}^{3} p_{Z j} \eta_{Z j} Z_{j}\right]=z_{j}
$$

where $Z_{x j}$ is the CES aggregate of intermediate goods and $\varepsilon>1$ is the elasticity of substitution between the various intermediates. $Z_{j}$ is the output of production of intermediate producer in $j$ supplying intermediate goods domestically, $\eta_{Z j}$ is the number of suppliers of intermediate goods in $j, p_{z j}$ is price of intermediate goods in $j$ and $z_{j}$ is the amount of intermediates used for $X$-good production in $j$. Demand for intermediate goods is written by

$$
Z_{j}=p_{z j}^{-\varepsilon} P_{z j}^{\varepsilon} z_{j}
$$

where the CES price index for intermediates is given by:

$$
P_{Z j}=\left[\sum_{j=1}^{3} \eta_{Z j}\left(p_{Z j}\right)^{1-\varepsilon}\right]^{\frac{1}{1-\varepsilon}}
$$

The production of the intermediate goods for local markets in country $j\left(z_{j}\right)$ is given by Cobb-Douglas production function:

$$
z_{j}=A S_{Z j}^{\beta} L_{Z j}^{1-\beta}
$$


where $S$ and $L$ are the quantities used of skilled and unskilled labor in country j to produce intermediate inputs $\left(Z_{j}\right), 0<\beta<1$ is the elasticity of substitution between intermediates. The above technology yields the following conditional factor demands and input coefficients:

$$
\begin{gathered}
S_{Z j}=z_{j} \underbrace{\frac{1}{A}\left(\frac{w_{L j}}{w_{S j}} \cdot \frac{\beta}{1-\beta}\right)^{1-\beta}}_{a_{S Z}} \\
L_{Z j}=z_{j} \underbrace{\frac{1}{A}\left(\frac{w_{S j}}{w_{L j}} \cdot \frac{1-\beta}{\beta}\right)^{\beta}}_{a_{L Z}}
\end{gathered}
$$

where $\mathrm{a}_{S Z}$ and $\mathrm{a}_{L Z}$ are country specific input coefficients for skilled and unskilled labor, respectively, for intermediate goods production.

An intermediate goods producer in the intermediate goods market equilibrium is faced with local demand:

$$
Z_{j}=p_{Z j}^{-\varepsilon} P_{Z j}^{\varepsilon} a_{Z X}\left(\eta_{j} X_{j}+\eta_{h} X_{h}+\eta_{v} X_{v}\right)
$$

Assuming that intermediate goods production is under Dixit and Stiglitz (1977) framework which requires free entry and exit condition, price of intermediate goods in host-country firms is given as:

$$
p_{Z j}\left[1-\frac{1}{\varepsilon}\right] \leq c_{Z j}
$$

where $c_{Z j}$ is marginal cost of intermediate goods producer in country $j$.

\section{B. Proof of the Proposition}

We first implicitly differentiate equation (8) with respect to $\eta_{h}$

$$
\frac{d I_{j}}{d \eta_{h}}=\frac{\frac{\varepsilon}{I_{j}^{1-\varepsilon}}}{(1-\varepsilon) \alpha M_{j}}\left(\begin{array}{c}
P_{j}^{1-\varepsilon} \frac{d \eta_{j}}{d \eta_{h}}+P_{h}^{1-\varepsilon}+P_{v}^{1-\varepsilon} \frac{d \eta_{v}}{d \eta_{h}}+\left[P_{i} 1+t_{i j} 1+\tau_{i j}\right]^{1-\varepsilon} \frac{d \eta_{i}}{d \eta_{h}} \\
+\left[P_{f}\left(1+t_{f j}\right)\left(1+\tau_{f j}\right)\right]^{1-\varepsilon} \frac{d \eta_{f}}{d \eta_{h}}
\end{array}\right)
$$

and plug the price of differentiated goods from equations (2) to (6) into (A9), which simplifies to:

$$
\frac{d I_{j}}{d \eta_{h}}=\frac{\frac{\varepsilon}{1-\varepsilon}}{\alpha M_{j}} \frac{X_{h} P_{h}}{(1-\varepsilon)}\left[1+B \frac{d \eta_{j}}{d \eta_{h}}+C \frac{d \eta_{v}}{d \eta_{h}}+D \frac{d \eta_{i}}{d \eta_{h}}+E \frac{d \eta_{f}}{d \eta_{h}}\right]=\frac{\frac{\varepsilon}{1-\varepsilon}}{\alpha M_{j}} \frac{X_{h} P_{h}}{(1-\varepsilon)} A
$$


with:

$$
B=\frac{X_{j} P_{j}}{X_{h} P_{h}} ; C=\frac{X_{v} P_{v}}{X_{h} P_{h}} ; D=\frac{X_{i} P_{i}\left(1+t_{i j}\right)\left(1+\tau_{i j}\right)}{X_{h} P_{h}} ; E=\frac{X_{f} P_{f}\left(1+t_{f j}\right)\left(1+\tau_{f j}\right)}{X_{h} P_{h}}
$$

The denominators of equation (A10) are obviously negative since $\varepsilon>1$. The numerators of $B, C, D$ and $E$ (which respectively measure sales of the domestic firms, vertical MNE and imports from $i$ and $f$ ) are clearly positive. For simplicity and analytical tractability, we assume that $B, C, D$ and $\mathrm{E}$ are less than or equal to 1 , and $C+D+E<1$. Consequently, the numerator will be positive as long as $d \eta_{j} /$ $d \eta_{h}, d \eta_{v} / d \eta_{h}, d \eta_{i} / d \eta_{h}$ and $d \eta_{f} / d \eta_{h}$ are positive. In this case, $d I_{j} / d \eta_{h}<0$ since $\varepsilon>1$ means that consumer gains from the multinational entry with lower price and " $\mathrm{A}$ " results in the minimum level of the price index. However, in order to obtain how domestic firms adjust to keep their profits from the entry of MNEs, we must assume that the price index, $I_{j}$, remains constant $\left(d I_{j} / d \eta_{h}=0\right)$; horizontal MNEs perfectly substitute vertical MNEs in producing X-goods $\left(d \eta_{v} / d \eta_{h}=-1\right)$ although the motivations of both FDI are different; and the entry of multinational firms fully replaces imports from national firms $\left(d \eta_{i} / d \eta_{h}=-1\right.$ and $\left.d \eta_{f} / d \eta_{h}=-1\right)$. This gives:

$$
\frac{d \eta_{j}}{d \eta_{h}}=(C+D+E-1) \frac{X_{h} P_{h}}{X_{j} P_{j}} \leq 0
$$

which is true since $C, D$ and $E \in(0,1)$. The entry of MNEs is thus likely to crowd domestic firms out of the host market.

Next, we determine the spillover effects of FDI on backward and forward linkages. Differentiating equation (29) with respect to $\eta_{h}$ by holding the price unchanged gives:

$$
p_{Z j} \frac{d Z_{j}}{d \eta_{h}}=a_{Z X} c_{Z j} X_{j} \frac{d \eta_{j}}{d \eta_{h}}+a_{Z X} c_{Z j} X_{h} \frac{d \eta_{h}}{d \eta_{h}}+a_{Z X} c_{Z j} X_{v} \frac{d \eta_{v}}{d \eta_{h}}
$$

Equation (A12) indicates the value of intermediate goods used by capturing the forward and backward linkages between the downstream and the upstream industry. Since the entry of multinationals is very likely to increase the production of intermediate goods, it is reasonable to argue that $d Z_{j} / d \eta_{h}$ is positive. Thus, the output in the upstream industry will expand. In the model, this will give rise to a decrease in the price index of intermediate goods due to scale economies. In turn, 
this makes possible a reduction in the price of the downstream industry since intermediates are one of the inputs for the production of good $X$.

To support the paragraph above, we start plugging equation (A11) into (A12):

$$
p_{Z j} \frac{d Z_{j}}{d \eta_{h}}=(C+D+E-1) a_{Z X} \frac{c_{z j} X_{j}}{p_{j} X_{j}}+a_{Z X} \frac{c_{Z j} X_{h}}{p_{h} X_{h}}-a_{Z X} \frac{c_{Z j} X_{v}}{p_{h} X_{h}}
$$

The left side of (A13) shows the intermediate demand for X-good production while the right side shows the correlation between the multinational entry ( $\mathrm{h}$ and $\mathrm{v}$ ) and the use of local intermediate goods. Rearranging equation (A13) gives:

$$
\frac{d Z_{j}}{d \eta_{h}}=\frac{c_{Z j} a_{Z X}}{p_{Z j}}\left\{\frac{(C+D+E-1)}{p_{j}}+\frac{1-\left(X_{v} / X_{h}\right)}{p_{h}}\right\}>0
$$

It is more likely to be positive since $Z_{j}$ always leads to decreasing $p_{Z j}$ and $c_{Z j}$. This indicates that the entry of MNEs largely makes an expansion in upstream industry (producing intermediate goods). The higher demand for intermediate goods will make their price lower (equation A2 and A3). At the same time, the higher quantities of intermediate goods respond to the higher $X$-goods production shown in equation (A7). That is because intermediate goods produced in the upstream industry are completely employed as one of the inputs for the $X$-goods production in the downstream industry as given in equation (29).

Of course, costs for the $X$-goods production in the downstream industry given by equation (28) decrease because the price of intermediate goods in upstream industry is lower, as shown above. Moreover, under free entry and exit condition in intermediate goods production, the price of $X$-goods is likely to decrease when the price of intermediate goods as partly being costs of $X$-good production decrease.

From all of them, it is clear that the multinational entry results in an expansion in upstream industry $\left(d Z_{j} / d \eta_{h}\right)$ and then produces a higher production in downstream industry. Finally, the price of $X$-goods in host markets absolutely falls.

Q.E.D 